\title{
Research on the Curriculum Integration of the Course of Chinese Modern History Outline
}

\author{
Xu Xiaoshi \\ Jilin Agricultural University, Changchun ,China \\ E-mail: xiaoshitou2001xxs@163.com
}

Keywords: Chinese modern history teaching; teaching link; theoretical enlightenment; content integration

\begin{abstract}
Chinese modern history" teaching material has some defects in the historical facts structure and theory summary and so on. This paper discusses the three important links in the teaching of Chinese modern history. Import link is the starting point. It can induce students' professional learning interest and produce the new knowledge of the teaching materials to learn the desire to expand the connotation of the history of the students. The construction of historical fact is the main part of the history. Historical construction can not only highlight the political and military, but also to highlight the economic, cultural aspects of the content and the foreign relations and so on. The theoretical link is innovation. It is the theory and experience of historical law according to different time summed up.
\end{abstract}

\section{Introduction}

There are some problems in the history teaching of undergraduate course. Theoretical framework and content innovation are the most popular. Many important concepts, theoretical framework and historical conclusion are proposed and determined in the 40 and 50 time of twentieth Century. With the development of history, some concepts and conclusions are often one-sided and need to be revised and supplemented by the teaching staff in order to enrich and develop the teaching contents and methods of modern Chinese history. Problems in teaching material construction lead to the old teaching content. Education researchers can't update a lot of new knowledge and new research results in time, which is bound to affect the student's intellectual development and thinking of innovation [1]. Yuan Weishi proposed, curious, skeptical and critical research and innovation is the starting point [2]. Scholars point out other issues in the curriculum , including: pay attention to the teaching material and ignore the teaching outline; the lag of the teaching material; the lack of prospective of the subject research; Chinese modern history teaching and the world modern history teaching are out of line, etc[3]. Some scholars have put forward some corresponding countermeasures which include of using the flexible teaching methods and the use of modern teaching methods etc [4] [5].

This paper argues that there are some important links in undergraduate teaching, which must be paid attention to, especially the content innovation and theoretical enlightenment. If we ignore the content innovation and theoretical enlightenment, the university history teaching will be impossible to provide the undergraduate students with more new education and theoretical summary [6].

\section{Import link}

Import links include: the introduction of academic trends and difficulties. How to import the problem is a problem in the course of college history teaching. Commonly used import there are six kinds of methods: stories, allusions to import new lesson, this method students prefer; the second is poetry, mystery, songs, peer to peer into the new lessons, this method is wonderful; the third is with introduction and historical data to import new lesson, this method more old-fashioned, review questions into new courses. This method can arouse students' attention; the fifth is in problem solving, icons and film import new lesson. This method is simple and clear, more practical, with 
vertical and horizontal linkages or current affairs inducts the new class, and this method can to provide students with a Lenovo empty, so as to achieve to inspire students thinking. Only these methods are not enough in the course of college history teaching. The introduction of the relevant academic trends should be introduced in each chapter In the course of history teaching in universities. Not all of the academic trends are listed out, but the important content related to the academic dynamics as an introduction. If there is no academic dynamic profile, the university history teaching has become simple and the lack of depth.

Teachers need to introduce dynamic research in academic circles before the regular teaching of "self movement" this chapter. Dynamic research includes: first introduced before 1949 in old China for self-improvement movements of authoritative historical works; second introduced the new China first thirty years for the general situation on the research of the self strengthening movement; third academic research situation about the self strengthening movement in recent decades. Due to too much of these academic dynamic content can't be introduced one by one can only focus on the analysis highlights two problems is about self movement of the guiding ideology of the "Chinese style Westernization" evaluation and effect.

In addition to a brief introduction to academic dynamics, it is also necessary to prompt the difficulty and focus. For example, the curriculum focuses on the main content of the new deal and how to objectively evaluate the new deal in the new deal in the late Qing Dynasty. The difficulty of the course is the relationship between the new deal and the revolution of 1911, the reason and the lesson of the failure of the new deal in the late Qing Dynasty. University History undergraduate teaching needs to have substantial content and depth.

\section{Main link}

The main part is to show the real history. How to create an efficient classroom? The content construction of the main teaching link is an important method and the main method to create a highly effective university history class and it is also an important way to promote the democratic teaching in University. To complete the construction of each chapter of the main teaching links, we must do the following.

First of all, we should have a systematic plan, organization and arrangement for each chapter. Both to highlight the key and can't ignore other parts. Taking this chapter of the first Opium War as an example, Teachers must consider how this chapter is organized. Specifically, the main frame of this chapter can be divided into four parts. The first part is Analysis of the historical background of the outbreak of the Opium war. The second part is the war and its course. The third part is the analysis of the causes of China's defeat and Its Enlightenment. The fourth part is the formation of the treaty system and its influence on modern china.

Secondly, it is necessary to make an objective and realistic narration of the historical content of each chapter and the promotion of the theory must be based on historical facts.

After the founding of new China, the original history textbook of China has been greatly modified for the sake of the political need. so the teaching material has lost the authenticity of history. Lin Zexu was perfectly said to be a great national hero in modern China. Although Lin Zexu to ban smoking, but he refused the Chinese and foreign trade. Further intensification of Sino foreign relations, China is in a more closed state. Accurately speaking, Lin Zexu is not a national hero but a no smoking hero. Zuo Zongtang recovered Xinjiang, he is the national hero. These historical facts are not reflected in the textbooks. In the teaching, the wanton destruction of the rebel action or the masses are depicted and the revolution to promote the liberation of productive forces.

Third, the historical construction of each chapter, not only highlight the political and military, but also to highlight the economic and cultural aspects of the content, but also can't ignore the contents of foreign relations and other aspects.

Modern Chinese history textbooks still have deficiencies which are from the original pay attention to political history, revolutionary history ignored economic history, cultural history, development to now attach too much importance to economic history, political history, while ignoring the military history and cultural history of education. Although the probability of failure is 
getting smaller and smaller, the teaching material is the basic historical facts to describe the political, economic, military and cultural history of modern society in a comprehensive way. The Boxer Uprising and the reform movement of 1898, the Eight Power Allied forces battle together etc.. Both of them are the historical events of China in 1896 and 1901. These events from the political, economic, military, diplomatic and other aspects of learning, but also has the significance and value of historical research.

Fourth, some important historical facts can't be downplay or ignore because of political reasons, otherwise it will cause the development history of fracture. For a long time, because of the political reasons or the deviation of thinking, some time period of history and the reality has certain deviation. Teachers should take an objective attitude in the teaching of historical events, remove the political bias.

\section{Theoretical link}

Theoretical link is the summary of experience and theory. The theory of modern Chinese history is a very important part of teaching. Theory is not produced or created by human, but is abstracted and summarized from the historical event. Both the experience and the theory are summed up from each of the major events, each of which is an important period of time and each major historical event. These theories are instructive and have educational significance to the later generations of Chinese society, which is of great significance to the development of contemporary China. These theories are closely related to the basic clues of Chinese modern history.

In nineteenth Century 40 - 60 years, we need to sum up experience and lessons after The Second Opium War. History of the seventy years of the late Qing Dynasty show that the traditional society to the transformation of modern society is the trend of Chinese society and the trend of the development of modern times, but the history of the revolution of 1911 but completely changed the direction of history. Although the establishment of the Nanjing national government is a step in the modernization construction and development of the Chinese society, then the two world events that took place have finally changed the direction of China's historical development. The first event is the establishment of the socialist theory of Marx and the great influence of the Soviet Socialist Countries after the establishment of the Soviet Socialist countries. Second event is Japan launched a comprehensive war of aggression against china. These two events eventually changed the direction of the development of China's history.

\section{Conclusion}

To sum up, college teaching is a comprehensive project, "award of the fish, as delegated to the fish". Chinese modern history should pay attention to the link above, can improve the quality of teaching, in order to cultivate a high quality of socialist construction personnel.

\section{References}

[1] Xu Xiuyi. The innovation of teaching content and practice of the modern history of China[J]. Suzhou Journal of Chinese Academy of science, 2002(2):93-94.

[2] Yuan Weishi. Some problems in the teaching of Chinese modern history[J]. Middle school history teaching Study, 2012:4-13..

[3] Xu Weimin, Wei FA. Several problems of teaching China modern history[J]. Journal of Anqing Teachers College: Social Science Edition, 2000(6):15-17.

[4] Lu Ling. Problems and Countermeasures in the teaching of modern Chinese history in universities and colleges [J].Journal of Chifeng University: Natural Science Edition, 2013(8):246-247.

[5]Yang Jinluan. Exploration and thinking of research teaching in Colleges and Universities -- A 
Case Study on the teaching of Chinese modern history as an example [J]. High education research and practice, 2003(3): 33-35.

[6]Wang Rui. An analysis of the role of patriotism in the teaching of Chinese modern history[J]. Journal of Harbin municipal Party school, 2005(4): 78-80. 